\title{
Drug Use and Abuse Prevention Concerns in Rural Communities in Enugu State Nigeria
}

\author{
Samuel I. C. Dibia ${ }^{1}$, Evelyn N. Nwagu ${ }^{1} \&$ Amelia N. Odo ${ }^{1,2}$ \\ ${ }^{1}$ Department of Human Kinetics and Health Education, University of Nigeria, Nsukka, 410001 Nsukka, Nigeria \\ ${ }^{2}$ Department of Anthropology, Michigan State University, MI, Nigeria \\ Correspondence: Evelyn N. Nwagu, Department of Human Kinetics and Health Education, University of Nigeria, \\ Nsukka, 410001 Nsukka, Nigeria. Tel: 234-813-970-7903. E-mail: evelyn.nwagu@unn.edu.ng
}

Received: December 14, 2019 Accepted: January 13, 2020 Online Published: January 30, 2020

doi:10.5539/gjhs.v12n2p78 URL: https://doi.org/10.5539/gjhs.v12n2p78

This project was funded by the Tertiary Education Trust Fund (TETFund) Institution Based Reseach (IBR) grant (TETFUND/DESS/UNN/NSUKKA/RP/VOL.X)

\begin{abstract}
Drug abuse among any population is harmful and constitutes an issue of great concern for health professionals and the entire community. This study focuses on identification of level of drug use and community concerns for preventing drug abuse in two rural communities in Enugu north senatorial zone, Enugu State, Nigeria. We conducted a community-based cross sectional study in Enugu North senatorial zone of Enugu state Nigeria. All adults and youths 10 years and above who were residing in the communities for the past two years were the study population. Simple random sampling by balloting was used to select two communities. Proportionate random sampling was used to select 290 participants comprising 147 males and 133 females for the study. Questionnaire was used to collected data. The data were analyzed by using IBM Statistical Package for Social Science version 20. Descriptive statistics, chi square, Fisher's exact test and the Monte Carlo test were computed for the data. The most commonly used substances by community members were alcohol, cigarette and cannabis. Greater proportion of community members (57\%) frown at abuse of substances. Majority of community members $(87 \%)$ wished that drug abuse will stop in the community, 3.6\% do not wish that it will stop and $9.4 \%$ do not care whether it stopped or not. The study has revealed areas of community concern and lack of concern for preventing drug abuse. These are hoped to guide drug abuse prevention intervention in the area of study.
\end{abstract}

Keywords: community, drug use, drug abuse, concerns, alcohol, Nigeria

\section{Introduction}

The increasing social ills world over have their roots in drug abuse in some ways. The third revised Diagnostic and Statistical Manual of Mental Disorders (DSM-IIIR), defined drug abuse as "a maladaptive pattern of use indicated by continued use despite knowledge of having a persistent or recurrent social, occupational, psychological or physical problem that is caused or exacerbated by the use [or by] recurrent use in situations in which it is physically hazardous (American Psychiatric Association, 1987). Drug abuse has contributed to the increase in crime rate and insurgency in many nations (Ewetan \& Urhie, 2014). Globally, drug abuse has become a big challenge to public health and even to security of many nations. This is due to the fact that drug abuse is usually accompanied by mental disorder, behavioural and social problems (Bröning et al., 2012).

In Nigeria, drug abuse has been a long-standing public health and social problem, with alcohol, cigarette and cannabis being among the most commonly abused (Nwoga et al., 2019). Of particular concern are drug abuse rates among young people in Nigeria. Drug abuse among any population is harmful and constitutes an issue of great concern for health professionals. Drug use and abuse has serious impacts on individuals, families and communities, and its effects are cumulative, contributing to social, physical, and mental health problems (Ostaszewski \& Zimmerman, 2006). Drugs abused in Nigeria are also increasing to include common household products (Etim, 2017). This makes it more difficult to control drug abuse since many of these substances are readily available.

Household products that are commonly abused include inhalable and ingestible legal products such as volatile 
solvents - comprising liquids that can dissolve a number of other substances including paints, thinners, gasoline, and glue, aerosols, disinfectant liquids, mouthwash, and other products high in ethanol (John et al., 2007; Gruenewald, Johnson, Shamblen, Ogilvie \& Collins, 2009). The abuse of these substances presents a number of prevention challenges, because there is no law forbidding the use of these substances. Many products widely available in retail stores, homes, and schools can be abused and share many characteristics of availability in common with other abused but legal products, such as alcohol and tobacco, while subjected to few formal controls.

A casual observation of the communities in Enugu North senatorial zone where this study was conducted will quickly reveal different drug related problems. In these communities, it is not uncommon to find many youths and adults alike roaming the urban and rural streets aimlessly. The number of mentally challenged who parade the streets in these communities has also continued to increase. Drinking bars and joints for cannabis have also become highly lucrative business in these communities. Crime and other social vices are also increasing in these communities. Drug abuse directly and indirectly produces many physical, mental, social health problems among the abusers (WHO, 2012). Several factors capable of intensifying the risks for initiating and continuing drug abuse such as poor socio-economic status, poor quality of parenting, peer group influence, and biological predispositions towards drug addiction (Solis, Shadur, Burns \& Hussong, 2012) abound in the area of study.

Preventing drug abuse requires concerted efforts by all. It requires the community to prevent drug and alcohol use among young people. Effectively addressing substance abuse requires awareness and understanding of current drugs of abuse and related concerns (Radin et al 2015). Communities' perception of drug abuse determines the community norm and their level of concern for preventing drug abuse. Historically, women using substances have always been frowned upon (Lal, et al., 2015). Community conferencing or meetings are important in addressing problems of drug abuse in the community. Such a conference brings together, in the wake of a serious incident, the offender, his or her victim(s) and the victim's family and appropriate school personnel in order to explore the harm done to all those affected, to decide what needs to be done to repair that harm and how to minimize the chance of it happening again (UNODC, 2004). Community programmes such as media campaigns, policies and regulations that restrict access to alcohol, tobacco, or other drugs, are forms of drug abuse prevention interventions. Such programmes need to strengthen norms against drug use in all drug abuse prevention settings, including the family and the school. In addition, prevention programming should be adapted to address the specific nature of the drug abuse problem in the local community (NIDA, 2007).

The Community organization theory stresses the active involvement and development of communities to address health and social problems. Key features include understanding the root causes of problems, focusing on specific concerns, engaging in effective problem solving, encouraging active community participation, and gaining the power to produce lasting change. A community concerned about alcohol problems may come together to make rules and regulations, or policies regarding the number and concentration of alcohol outlets or the hours and days when alcohol is sold (Substance Abuse and Mental Health Services Administration, 2017).

Having facts can help you set priorities. Parents in a community may be concerned about places where young people gather to abuse substances. Community members may be unaware that drug problems exist or believe preventing drug abuse is not their responsibility. Effective community participation in substance abuse prevention requires some level of awareness and understanding of trends in drug abuse in the community by members of the community. Literature suggests that mobilizing community for preventing drug abuse may best begin by identifying within each community the culture-based strengths for supporting health promotion and prevention rather than treating problems (Echo-Hawk, 2011). This leads to a recognition and understanding of local challenges, and utilizing local knowledge, expertise, and other resources to build wellness.

Assessment of community drug problems according to SAMAHA (2019) should involve asking questions to ascertain what substances are being abused in the community, how often the substance abuse is occurring, which substances are abused the most, where the substance abuse is occurring, and who is experiencing more of the substance abuse problem. There are only few studies focusing on community prevention of drug abuse in the area of study, and none has examined community concerns for preventing drug abuse and how that might influence how they view and perform prevention roles. This study therefore focuses on identification of level of drug use and community concern for prevention drug abuse in two rural communities in Enugu north senatorial zone.

Specific objectives were to identify: commonly abuse substances in the communities; Community efforts and concerns for preventing drug abuse; and demographic variables associated with community efforts and concerns for prevention of drug abuse

\section{Methods}

We conducted a community-based cross sectional study in Enugu North senatorial zone of Enugu state Nigeria. 
The zone is made up of six local government areas (LGAs) namely; Igbo-Etiti, Igbo-Eze North, Igbo-Eze South, Nsukka, Udenu, and Uzo-Uwani LGAs. Indigenes of this zone are Igbos and they live communal life to a large extent. There is high consumption of alcohol particularly palm wine and local gin (kai kai) which are produced locally in the zone.

All adults and youths (10 years and above) who are resident in the communities (at least for the past two years) were the study population. The size of the population was estimated to be 209,670 persons. A multistage stage sampling procedure was employed to select a total of 290 participants. At stage one, simple random sampling was used to select two local government areas, Nsukka and Udenu local government areas. From the two LGAs, one community was selected from each of the LGA using simple random sampling of balloting without replacement. The third stage involves the selection of 290 participants using the proportionate random sampling technique.

The instrument for data collection was a questionnaire designed by the researchers and face validated by two experts in public health education and one in measurement and evaluation. The instrument consists of three sections, A B and C. Section A was used to collect information on the participants' demographic information (The demographic characteristics of participants are shown in Table I). Section B contains questions on the prevalent substances of abuse; while section $\mathrm{C}$ contains questions on community and participants' efforts and disposition to preventing substance abuse in the community. There were eight questionnaire items in section $\mathrm{C}$ ant the items and their numbers are: 1. Are there places where people gather to use substances? 2. Do members of your community frown at abuse of substances? 3. Have community leaders met to talk about prevention of drug abuse for the past one year? 4. Have there been programmes (campaign, workshop etc.) on drug abuse in the community since the past one year? 5. Are you willing to attend a sensitization programme on drug abuse if mounted? 6 . Are you aware of the dangers of drug abuse? 7. Do you wish that drug abuse will stop in your community? 8 . Do you wish to be part of the movement or crusade to stop drug abuse in the community?

Out of the 290 copies of questionnaire distributed, only 277 were duly filed and returned. Only these were used for data analysis. The data were analyzed by using IBM Statistical Package for Social Science version 20. Descriptive statistics, chi square, Fisher's exact test and the Monte Carlo test were computed for data. We computed the Fisher's exact test for contingency tables with one degree of freedom or when more than $20 \%$ of the cells in a contingency table had expected count less than 5. Literature has shown that the goal in Exact Tests is to enable a researcher make reliable inferences when the data is small, sparse, heavily tied, or unbalanced and the validity of the corresponding large sample theory is in doubt (Cengiz, Fikret, \& SÖNMEZ, 2009). The exact and Monte Carlo methods provide a powerful means for obtaining accurate results when: a data set is small, tables are sparse or unbalanced, the data are not normally distributed, or the data fail to meet any of the underlying assumptions necessary for reliable results using the standard asymptotic method (Metha \& Patel, 2009). If a data set is too large for the exact algorithms, Monte Carlo algorithms are substituted in their place in order to estimate the exact $p$ values to any desired level of accuracy (Metha \& Patel, 2009).

Ethical approval for the study was granted by Faculty of Education, University of Nigeria, Research Ethics Committee (REC/FE/2018/000008). Informed consent was obtained from participants. 


\section{Results}

Table 1. Demographic Characteristics of Respondents $(n=277)$

\begin{tabular}{|c|c|c|}
\hline Variable & Frequency & Percentage \\
\hline \multicolumn{3}{|l|}{ Age } \\
\hline $10-17$ years & 53 & 19.1 \\
\hline $18-25$ years & 104 & 37.5 \\
\hline $26-35$ years & 72 & 26.0 \\
\hline $36-59$ years & 41 & 14.8 \\
\hline 60 years and above & 7 & 2.5 \\
\hline \multicolumn{3}{|l|}{ Educational Level } \\
\hline No formal education & 12 & 4.3 \\
\hline Primary & 11 & 4.0 \\
\hline Secondary & 181 & 65.3 \\
\hline Tertiary education & 73 & 26.4 \\
\hline \multicolumn{3}{|l|}{ Occupation } \\
\hline Unemployed & 126 & 45.5 \\
\hline Self employed & 91 & 32.9 \\
\hline Civil servant/Private firm employed & 48 & 17.3 \\
\hline Others (please identify) & 12 & 4.3 \\
\hline \multicolumn{3}{|l|}{ Marital status } \\
\hline Never Married & 178 & 64.3 \\
\hline Married or Living together & 95 & 34.3 \\
\hline Divorced/Separated/Widowed & 4 & 1.4 \\
\hline \multicolumn{3}{|l|}{ Gender } \\
\hline Male & 147 & 53.1 \\
\hline Female & 130 & 46.9 \\
\hline Total & 277 & 100.0 \\
\hline \multicolumn{3}{|l|}{ Location } \\
\hline Obukpa & 117 & 42.2 \\
\hline Obollo & 160 & 57.8 \\
\hline \multicolumn{3}{|l|}{ Income } \\
\hline Below N10000 & 163 & 58.8 \\
\hline N 10000 - N 49000 & 74 & 26.7 \\
\hline N 50000 - N 150000 & 32 & 11.6 \\
\hline Above N 150000 & 8 & 2.9 \\
\hline \multicolumn{3}{|l|}{ Religion } \\
\hline Traditional & 13 & 4.7 \\
\hline Christianity & 255 & 92.1 \\
\hline Muslim & 9 & 3.2 \\
\hline Total & 277 & 100.0 \\
\hline
\end{tabular}

The data in Table 1 shows that $37.5 \%$ of the participants were 18 to 25 years of age, $69.3 \%$ had secondary 
education, $45.5 \%$ had no employment, $64.3 \%$ were never married, $53.1 \%$ were males, $58.8 \%$ earn below N10,000.00 as monthly income and greater part of the participants were Christians (92.1\%).

Table 2. Commonly used substances in the community

\begin{tabular}{lll}
\hline Substances & $\mathrm{f}$ & $\%$ \\
\hline Cigarette & 221 & 79.8 \\
Cannabis & 167 & 60.3 \\
Alcohol & 249 & 89.9 \\
Smokeless tobacco (Snuff) & 156 & 56.3 \\
Tramadol & 165 & 59.6 \\
Others (Superglue, etc) & 15 & 5.4 \\
\hline
\end{tabular}

Table 2 shows that the most commonly used substances by community members were alcohol (89.9\%), cigarette (79.8\%) and cannabis $(60.3 \%)$.

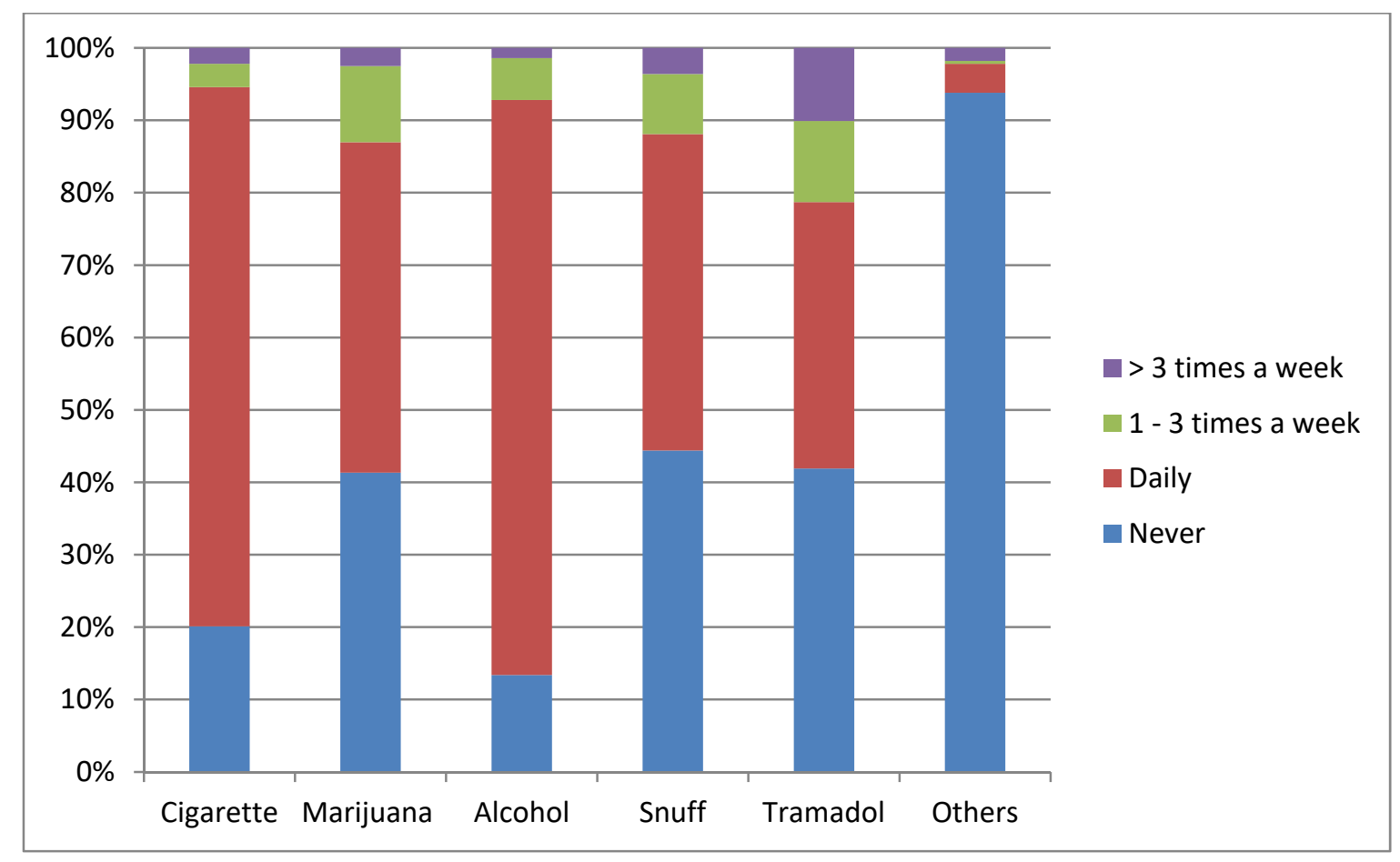

Figure 1. Frequency of use of substances by community members in percentage

Figure 1 shows that the frequency of daily consumption of alcohol by community members was highest at $79.4 \%$. Other substances indicated where house hold products such as super glue and the daily frequency consumption of these by community members was $4 \%$. 
Table 3. Frequencies of concerns by demographic variables

\begin{tabular}{|c|c|c|c|c|c|c|c|c|c|c|c|c|c|c|c|c|c|c|c|c|c|}
\hline \multirow{3}{*}{ Variables } & \multicolumn{21}{|c|}{ Questionnaire Items } \\
\hline & item 1 & & & item 2 & & & item 3 & & & item 4 & & item 5 & & & item 6 & & item 7 & & & item 8 & \\
\hline & $\overleftrightarrow{8}$ & z & 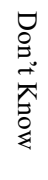 & $\overleftrightarrow{\mathbb{Q}}$ & z & 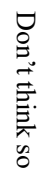 & $\underset{\&}{\&}$ & ž & 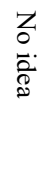 & $\overleftrightarrow{8}$ & 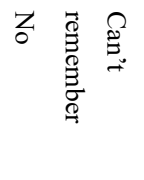 & 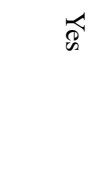 & ž & 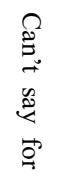 & 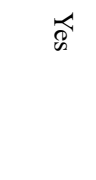 & z & $\underset{\&}{\&}$ & z & 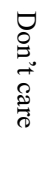 & $\underset{\&}{\mathscr{8}}$ & 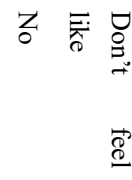 \\
\hline
\end{tabular}

\section{Age}

$\begin{array}{lllllllllllllllllllllllllll}10-17 \text { years } & 23 & 6 & 24 & 34 & 5 & 14 & 23 & 8 & 22 & 26 & 6 & 21 & 32 & 6 & 15 & 49 & 4 & 49 & 1 & 3 & 34 & 6 & 13\end{array}$ $\begin{array}{llllllllllllllllllllllll}18-25 \text { years } & 59 & 14 & 31 & 57 & 17 & 30 & 29 & 17 & 58 & 37 & 29 & 38 & 68 & 11 & 25 & 93 & 11 & 91 & 4 & 9 & 88 & 7 & 9\end{array}$ $\begin{array}{lllllllllllllllllllllllllll}26-35 \text { years } & 40 & 14 & 18 & 42 & 13 & 17 & 20 & 17 & 35 & 21 & 34 & 17 & 46 & 12 & 14 & 50 & 22 & 63 & 3 & 6 & 56 & 7 & 9\end{array}$ $\begin{array}{llllllllllllllllllllllll}36-59 \text { years } & 19 & 12 & 10 & 21 & 9 & 11 & 9 & 11 & 21 & 8 & 18 & 15 & 25 & 7 & 9 & 32 & 9 & 32 & 2 & 7 & 30 & 4 & 7\end{array}$

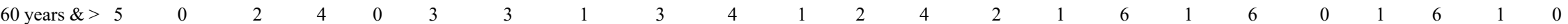

Education

$\begin{array}{llllllll}7 & 1 & 3 & 5 & 2 & 4 & 5\end{array}$

$\begin{array}{llllllllllllllllllllllllllllll}\text { SE } & 95 & 26 & 60 & 104 & 29 & 48 & 57 & 36 & 88 & 63 & 59 & 59 & 107 & 27 & 47 & 151 & 30 & 160 & 6 & 15 & 137 & 16 & 28\end{array}$

$\begin{array}{llllllllllllllllllllllllll}\mathrm{TE} & 38 & 18 & 17 & 44 & 12 & 17 & 18 & 15 & 40 & 22 & 27 & 24 & 57 & 6 & 10 & 64 & 9 & 65 & 2 & 6 & 60 & 7 & 6\end{array}$

Occupation

$\begin{array}{lllllllllllllllllllllllllllll}\text { Unemploye } & 62 & 15 & 49 & 79 & 16 & 31 & 42 & 22 & 62 & 53 & 30 & 43 & 82 & 17 & 27 & 111 & 15 & 112 & 6 & 8 & 99 & 11 & 16\end{array}$

$\begin{array}{lllllllllllllllllllllllllll}\text { Self } & 52 & 15 & 24 & 48 & 16 & 27 & 29 & 21 & 41 & 28 & 36 & 27 & 53 & 17 & 21 & 63 & 28 & 74 & 4 & 13 & 67 & 11 & 13\end{array}$

employed

$\begin{array}{lllllllllllllllllllllllllllll}\text { Civil servant } & 23 & 13 & 12 & 28 & 9 & 11 & 10 & 11 & 27 & 13 & 20 & 15 & 35 & 4 & 9 & 44 & 4 & 43 & 0 & 5 & 39 & 3 & 6\end{array}$

Others

Marital

status

$\begin{array}{lllllllllllllllllllllllllllll}\text { Never } & 97 & 24 & 57 & 111 & 24 & 43 & 65 & 29 & 84 & 71 & 45 & 62 & 112 & 23 & 43 & 157 & 21 & 159 & 7 & 12 & 139 & 16 & 23\end{array}$

married

Married

$45 \quad 22$

28

$44 \quad 20 \quad 31$

17

$54 \quad 22$ 


\begin{tabular}{|c|c|c|c|c|c|c|c|c|c|c|c|c|c|c|c|c|c|c|c|c|c|c|c|}
\hline Divorced & 4 & 0 & 0 & 3 & 0 & 1 & 2 & 1 & 1 & 3 & 1 & 0 & 0 & 3 & 1 & 3 & 1 & 2 & 0 & 2 & 3 & 1 & 0 \\
\hline \multicolumn{24}{|l|}{ Gender } \\
\hline Male & 78 & 28 & 41 & 84 & 28 & 35 & 55 & 28 & 64 & 51 & 53 & 43 & 98 & 21 & 28 & 122 & 25 & 123 & 8 & 16 & 109 & 16 & 22 \\
\hline Female & 68 & 18 & 44 & 74 & 16 & 40 & 29 & 26 & 75 & 45 & 35 & 50 & 77 & 17 & 36 & 108 & 22 & 118 & 2 & 10 & 105 & 9 & 16 \\
\hline \multicolumn{24}{|l|}{ Location } \\
\hline Obukpa & 54 & 14 & 49 & 69 & 11 & 37 & 41 & 17 & 59 & 50 & 19 & 48 & 73 & 18 & 26 & 102 & 15 & 103 & 5 & 9 & 90 & 11 & 16 \\
\hline Obollo & 92 & 32 & 36 & 89 & 33 & 38 & 43 & 37 & 80 & 46 & 69 & 45 & 102 & 20 & 38 & 128 & 32 & 138 & 5 & 17 & 124 & 14 & 22 \\
\hline \multicolumn{24}{|l|}{ Income } \\
\hline Below 10k & 84 & 22 & 57 & 93 & 22 & 48 & 54 & 25 & 84 & 62 & 39 & 62 & 102 & 19 & 42 & 139 & 24 & 146 & 5 & 12 & 127 & 14 & 22 \\
\hline $10-49 \mathrm{k}$ & 38 & 15 & 21 & 40 & 14 & 20 & 21 & 20 & 33 & 19 & 32 & 23 & 49 & 14 & 11 & 56 & 18 & 58 & 4 & 12 & 53 & 9 & 12 \\
\hline $50-150 \mathrm{k}$ & 20 & 7 & 5 & 20 & 7 & 5 & 9 & 6 & 17 & 13 & 15 & 4 & 20 & 3 & 9 & 27 & 5 & 30 & 1 & 1 & 28 & 1 & 3 \\
\hline Above 150k & 4 & 2 & 2 & 5 & 1 & 2 & 0 & 3 & 5 & 2 & 2 & 4 & 4 & 2 & 2 & 8 & 0 & 7 & 0 & 1 & 6 & 1 & 1 \\
\hline \multicolumn{24}{|l|}{ Religion } \\
\hline Traditional & 8 & 2 & 3 & 8 & 3 & 2 & 5 & 2 & 6 & 6 & 3 & 4 & 7 & 3 & 3 & 5 & 8 & 8 & 2 & 3 & 8 & 3 & 2 \\
\hline Christianity & 133 & 43 & 79 & 143 & 39 & 73 & 77 & 49 & 129 & 85 & 84 & 86 & 163 & 33 & 59 & 217 & 38 & 226 & 7 & 22 & 201 & 20 & 34 \\
\hline Muslim & 5 & 1 & 3 & 7 & 2 & 0 & 2 & 3 & 4 & 5 & 1 & 3 & 5 & 2 & 2 & 8 & 1 & 7 & 1 & 1 & 5 & 2 & 2 \\
\hline \multirow[t]{3}{*}{ Total } & $146(5$ & $46(16.6$ & $85(30$. & 158( & $44(1$ & $75(27.1$ & $84(30.3$ & $54(19.5$ & $139(50$ & $96(34$. & $88(3$ & 93(33. & $175(63$ & $38(13$. & $64(23$. & $230(8$ & $47(17$ & $241(87$ & $10(3$ & $26(9$ & $214(7$ & $25(9$. & $38(13$. \\
\hline & $2.7 \%)$ & $\%)$ & 7) & 57.0 & $5.9 \%$ & $\%)$ & $\%)$ & $\%)$ & $.2 \%)$ & $6 \%)$ & $1.8 \%$ & $6 \%)$ & $.2 \%)$ & $7 \%)$ & $1 \%)$ & $3 \%)$ & $\%)$ & $\%)$ & $6 \%)$ & $4 \%)$ & $7.3 \%)$ & $0 \%)$ & $7 \%)$ \\
\hline & & & & $\%)$ & ） & & & & & & ) & & & & & & & & & & & & \\
\hline
\end{tabular}

Greater proportion of community members (57\%) frown at abuse of substances. This proportion was gotten from the total percentage of respondents saying yes to item 2 which asked the question: Do members of your community frown at abuse of substances? Majority of community members (87\%) wished that drug abuse will stop in the community, $3.6 \%$ do not wish that it will stop and $9.4 \%$ do not care whether it stopped or not. 
Table 4. Chi square calculations for community concern for drug abuse

\begin{tabular}{|c|c|c|c|c|c|c|c|c|c|c|c|c|c|c|c|c|}
\hline \multirow[t]{3}{*}{ Variables } & \multicolumn{16}{|c|}{ Questionnaire Items } \\
\hline & \multicolumn{2}{|c|}{ Item 1} & \multicolumn{2}{|l|}{ Item 2} & \multicolumn{2}{|l|}{ Item 3} & \multicolumn{2}{|l|}{ Item 4} & \multicolumn{2}{|l|}{ Item 5} & \multicolumn{2}{|l|}{ Item 6} & \multicolumn{2}{|l|}{ Item 7} & \multicolumn{2}{|l|}{ Item 8} \\
\hline & $\chi^{2}$ Value & Sig. P & $\chi^{2}$ Value & Sig. P & $\chi^{2}$ Value & Sig. P & $\chi^{2}$ Value & Sig. P & $\chi^{2}$ Value & Sig. P & $\chi^{2}$ Value & Sig. P & $\chi^{2}$ Value & Sig. P & $\chi^{2}$ Value & Sig. P \\
\hline Age & 12.566 & $.111^{\mathrm{a}}$ & 5.295 & $.726^{\mathrm{a}}$ & 8.873 & $.337^{\mathrm{a}}$ & 26.154 & $.001^{* \mathrm{~b}}$ & 4.712 & $.788^{\mathrm{a}}$ & 16.548 & $.003^{*}$ & 5.409 & $.677^{\mathrm{a}}$ & 11.817 & $.174^{\mathrm{a}}$ \\
\hline Education & 6.172 & $.391^{\mathrm{a}}$ & 4.311 & $.632^{\mathrm{a}}$ & 7.041 & $.300^{\mathrm{a}}$ & $10.140^{\mathrm{a}}$ & $.108^{\mathrm{a}}$ & 14.096 & $.018^{* \mathrm{a}}$ & 6.281 & $.076^{\mathrm{a}}$ & 14.759 & $.011^{* \mathrm{a}}$ & 4.217 & .605 \\
\hline Occupation & 14.835 & .021 & 8.168 & .225 & 7.806 & .253 & 14.220 & $.024^{\mathrm{a}}$ & 13.315 & .037 & 19.588 & .000 & 6.758 & $.285^{\mathrm{a}}$ & 3.470 & $.742^{\mathrm{a}}$ \\
\hline Marital status & 6.454 & $.131^{\mathrm{a}}$ & 7.192 & $.095^{\mathrm{a}}$ & 12.742 & $.006^{\mathrm{a}}$ & 14.809 & $.002^{\mathrm{a}}$ & 9.998 & $.027^{\mathrm{a}}$ & 9.579 & $.006^{\mathrm{a}}$ & 8.545 & .062 & 2.275 & .637 \\
\hline Gender & 1.929 & .386 & 3.208 & .205 & 7.979 & .018 & 3.554 & .173 & 2.909 & .248 & .000 & 1.00 & 4.060 & .130 & 1.946 & .375 \\
\hline Location & 12.549 & .002 & 7.040 & .029 & 4.050 & .133 & 23.541 & .000 & .498 & .794 & 2.473 & $.145^{\mathrm{a}}$ & .891 & .627 & .035 & 1.000 \\
\hline Income & 7.217 & $.281^{\mathrm{a}}$ & 4.242 & .641 & 9.011 & $.154^{\mathrm{a}}$ & 18.032 & $.004^{\mathrm{a}}$ & 7.006 & $.290^{\mathrm{a}}$ & 5.101 & .156 & 7.484 & $.215^{\mathrm{a}}$ & 3.893 & $.655^{\mathrm{a}}$ \\
\hline Religion & .634 & .992 & 5.237 & $.228^{\mathrm{a}}$ & 1.753 & $.818^{\mathrm{a}}$ & 3.278 & $.513^{\mathrm{a}}$ & 2.432 & $.662^{\mathrm{a}}$ & 14.227 & $.001^{\mathrm{a}}$ & 10.814 & $.017^{\mathrm{a}}$ & 7.269 & $.070^{\mathrm{a}}$ \\
\hline
\end{tabular}

$\mathrm{a}=$ Fisher's exact use because the df was 1 or that more than $20 \%$ of the of the cells had expected count less than 5

$\mathrm{b}=$ Monte Carlo significance used because the data was too large for the exact algorithms

* = Significant at $P 0.05$ or less

There were significant differences in the proportion of community members who were aware of places where people gather to use substances (Item 1$)$ by occupation ( $p$ $=.021)$ and location $(p=.002)$. There were significant differences in the proportion of community members who frown at taking substances (Item 2$)$ by location $(p=.029)$. There were significant differences in the proportion of community leaders who had met to talk about prevention of drug abuse in the past one year (Item 3 ) by gender ( $p$ $=.018)$ and marital status $(p=.006)$. There were significant differences in the proportion of community members who conducted programmes (campaign, workshop etc.) on drug abuse in the community since past one year (Item 4) by age $(p=.001)$, occupation $(p=.024)$, marital status $(p=.002)$, location $(p=.000)$ and income $(p=.004)$. 


\section{Discussion}

\subsection{Commonly Abused Drugs}

The alarming increase in drug use and abuse in Nigeria calls for imminent redress. We found out that alcohol, cigarette and Indian hemp were the most commonly used substances in the area of study. Coincidentally, Adamson et al (2015) reported that the highest lifetime prevalence of alcohol use among males was recorded in the South-East (71.3\%) and the least in the North-West (9.4\%) Nigeria. Alcohol was the most used and abused (89.9\%) in the study. This finding yield to reports of other studies that alcoholic beverages are by far the most commonly used and abused of psychoactive substances, with an increasing use (Dawson, Goldstein, Saha \& Grant, 2015). Reports on the problems caused by alcohol intake are well documented (CDC, 2014; Rehm \& Hingson, 2013; Whiteford et al., 2013; WHO, 2012). Alcohol and other drugs are well known causes of morbidity, mortality, and social damage around the world, and are considered an important component of the global burden of disease (WHO, 2014). Yet, there is an increasing rate of consumption in the last decade (Begun \& Clapp, 2016). This is a challenge that requires multisectoral collaboration, sustainable solutions via significant, transformative, and groundbreaking innovations. Evidence-based community intervention and prevention efforts are necessary because effective integration of alcohol prevention and treatment strategies into routine practice requires significant "cultural" adaptations, particularly in community settings where social norms run counter to the aim of reducing alcohol misuse (Begun \& Clapp, 2016; Holleran Steiker, Grahovac, \& White, 2014).

From recent studies, Unaogu et al. (2017) identified cannabis and alcohol as most abused drugs among their study participants in Enugu State. In their study, patients at psychiatric hospitals were used for the study. This could attest to why cannabis got to above 81 percent at first use. Manyike et al., (2016) in a study to determine correlates for psychoactive substance use among boarding secondary school adolescents in Enugu State found out that cannabis was least used, whereas kola nut was the most used. This contradicts the current finding. It is possible anyways because Manyike et al were concerned with adolescents living in the dormitories where supervision and surveillances exist.

Sixty point three percent of the participant in the present study indicated that community members use cannabis. This is at variance with the reports of United Nations Office on Drugs and Crime UNODC, (2018) that canabis was the most widely used substance in the past year in Nigeria, followed by pharmaceutical opioids (mainly tramadol, and to a lesser extent codeine or morphine) and cough syrups containing codeine. However, the present study surveyed rural communities whilst considering persons from different ages, educational levels, marital status, income levels and locations. This shows how pattern of drug use can vary among different populations. More so, the participants in the present study responded based on what they perceived of the community. This is a new paradigm of exposing the ills in the society.

Tramadol and tobacco were also reported as substances used in the communities. This is in contrast to findings from some previous studies which had implicated them as the most abused illicit drugs (Idowu et al., 2018). Observation shows that youths cling to tramadol while the adults indulge in both tramadol and smokeless tobacco. Some studies have reported some erroneous views that could have spurred the community members to abuse these substances. Euphoric effects (Idowu, et al., 2018) enhancement of intellectual and academic performances (Idowu, 2018), experimentation (Idris \& Sambo, 2009), sexual function optimization (Abdel-etamid et al, 2016). Painkillers are the rave for recreational drug users the world over in recent times and Tramadol being the favourite of them is at the fulcrum of a very present drug problem in Nigeria, Enugu State inclusive. The social media is agog with tweets about tramadol trafficking, billions of naira worth of drugs seized, et cetera. The cheap pricing and easy to get from patent stores proliferate its consumption among the populace, especially the rural dwellers. The concerned agencies are doing their best to halt the transmission of tramadol but their efforts are predominantly in the urban areas.

\subsection{Community Efforts and Concerns for Preventing Drug Abuse}

There was a significant association between community frowning at taking of substances and locations. The position of any community on taking any substance depends on the value the community places in such substance. Sadock and Sadock (2003) affirmed that some substances of abuse, especially alcoholic beverages play significant social, economic, political and traditional roles in Africa, America and Europe. Members of rural communities in Enugu North Senatorial district use alcohol and tobacco for entertainment during events such as marriage, burial ceremonies, and other life events. This makes these substances readily available at no cost to young people in these communities. It is therefore not surprising that the use of these substances has continued to rise in rural communities despite the established relationships to some undesirable death, social, legal and economic outcomes (UNODC, 2018). What many community members in Enugu state of Nigeria frown at is heavy use of such 
substances as alcohol and its use by underage persons and women. Uses of illegal substances are however generally frowned at.

Items 3 to 6 (community leaders meeting to discuss drug abuse prevention; initiating programmes on drug abuse in the community; willingness to attend a sensitization programme on drug abuse if mounted; and awareness of the dangers of drug abuse) were significantly associated with marital status. We categorized marital status into three \{never married, married, and formerly married (separated, divorced and widowed)\}. The findings indicate that significant associations exist among participants based on their marital status and the efforts/concerns stated in items 3 to 6 . This is not surprising because the deeper one gets into family, the more concerned he or she gets about the wellbeing of the family even as it relates to drug use. It is therefore not surprising that the married more agreeable to attending sensitization programme on drug abuse prevention other categories Table 2.

Conducting a programme on drug abuse prevention in the communities was significantly associated with age, occupational status, marital status, income level and location. The never married who were mostly youth were more aware of programmes on preventing drug abuse but less likely to attend such programmes than the married participants. The primary objective of substance abuse prevention and its associated outcome research is drifting from promoting and maintaining abstinence using various combinations of psychological and pharmacological treatments to community programmes (Heinz et al, 2009). Our study shows that marital status is important for predicting substance use. Similarly, Heinz et al found out that being married and satisfied (having a close and personal relationship) appear to be a protective factor against relapse during treatment as well as predicts better substance use outcomes compared to being single, separated or divorced.

\subsection{Implication for Drug Abuse Prevention in the Community}

Substance abuse prevention efforts in rural communities should be specific to each community need for intervention. Such programmes should identify the strengths and weakness of the community to build on the strengths and while fixing the weaknesses (Oetting, Plested, Edwards, et al., 2014). Marital status should be given particular attention in drug abuse prevention efforts in rural communities. Our study has shown that being married has its strengths and weakness with regards to drug abuse prevention efforts. While the married individuals may show more concern, the never married may be more willing to participate in programmes aimed to prevent drug abuse

\section{Conclusion}

Alcohol, cigarette and cannabis were the most commonly used and abused substances in the study area. House hold products such as super glue and Tramadol were abused to a lesser extent. It was quite evident that these communities will benefit from drug abuse prevention intervention to enlighten and equip them to control of drug related problems in their communities. The findings of this study have highlighted the prevalent drugs of abuse and their patterns of use in the area of study. It has also shown the areas of community concern and lack of concern for preventing drug abuse. These are hoped to be of great benefits in mounting drug abuse prevention intervention in the area of study.

\section{Limitations}

Associations between the demographic characteristics of participants and community efforts and concerns were based only on non parametric tests since the data collected were nominal data.

\section{Acknowledgements}

This project was funded by the Tertiary Education Trust Fund (TETFund) Institution Based Reseach (IBR) grant (TETFUND/DESS/UNN/NSUKKA/RP/VOL.X)

We thank TETFund for providing the fund for this project.

\section{Competing Interests Statement}

The authors declare that there are no competing or potential conflicts of interest.

\section{References}

Abdel-Hamid, I. A., Andersson, K., Waldinger, M. D., \& Anis, T. H. (2016). Tramadol abuse and sexual function. Sexual Medicine Reviews, 4 (3), 235-246. https://doi.org/10.1016/j.sxmr.2015.10.014

Adamson, T. A., Ogunlesi, A. O., Morakinyo, O., Akinhanmi, A. O., Onifade, P. O., Erinosho, O., ... \& Olaniyan, O. (2015). Descriptive national survey of substance use in Nigeria. Journal of Addiction Research \& Therapy, 6 (234), 1-10. https://doi.org/10.4172/2155-6105.1000234 
American Psychiatric Association (1987). Diagnostic and statistical manual of mental disorders (3rd ed., revised).Washington, DC: American Psychiatric Association.

Begun, A. L., Clapp, J. D., \& The Alcohol Misuse Grand Challenge Collective. (2016). Reducing and preventing alcohol misuse and its consequences: A Grand Challenge for social work. Journal of Alcohol and Drug Research, 5(2), 73-83. https://doi.org/10.7895/ijadr.v5i2.223

Bröning, S., Kumpfer, K., Kruse, K., Sack, P. M., Schaunig-Busch, I., Ruths, S., ... \& Thomasius, R. (2012). Selective prevention programs for children from substance-affected families: a comprehensive systematic review. Substance Abuse Treatment, Prevention, and Policy, 7(1), 23. https://doi.org/10.1186/1747-597X-7-23

Cengiz, B. A. L., Fikret, E. R., \& SÖNMEZ, H. (2009). A Review of Statistical Techniques for 2x2 and RxC Categorical Data Tables In SPSS. Journal of Pediatric Sciences, 1 , e1 https://dergipark.org.tr/tr/download/article-file/178758

Centre for Disease Control and Prevention - CDC. (2014). Drug overdose deaths hit record numbers in 2014. Retrieved from https://www.cdc.gov/media/releases/2015/p1218-drug-overdose.html

Dawson, D. A., Goldstein, R. B., Saha, T. D., \& Grant, B. F. (2015). Changes in alcohol consumption: United States 2001-2 to 2012-13. Drug and Alcohol Dependence, 148, 56-61. https://doi.org/10.1016/j.drugalcdep.2014.12.016

Echo-Hawk H. (2011). Indigenous communities and evidence building. Journal of Psychoactive Drugs, 43(4); 269-275. https://doi.org/10.1080/02791072.2011.628920

Etim, I. O. (2017). Drug Abuse among our Youths. Available: nationonline.ng.net.>drugabuse (Accessed on18th March, 2018)

Ewetan, O. O., \& Urhie, E. (2014). Insecurity and Socio-Economic Development in Nigeria. Journal of Sustainable Development Studies, 5 (1), 40-63.

Gruenewald, P. J., Johnson, K., Shamblen, S. R., Ogilvie, K. A., \& Collins, D. (2009). Reducing adolescent use of harmful legal products: intermediate effects of a community prevention intervention. Substance use \& misuse, 44(14), 2080-2098. https://doi.org/10.3109/10826080902855223

Heinz, A., Beck, A., Grüsser, S. M., Grace, A. A., \& Wrase, J. (2009). Identifying the neural circuitry of alcohol craving and relapse vulnerability. Addiction Biology, 14(1), 108-118. https://doi.org/10.1111/j.1369-1600.2008.00136.x

Holleran Steiker, L. K., Grahovac, I., \& White, W. (2014). Social work and collegiate recovery communities. Social Work, 59(2), 177-180. https://doi.org/10.1093/sw/swu012

Idowu, A., Aremu, A. O., Olumide, A., \& Pginlaja, A. O. (2018). Substance abuse among students in selected secondary schools of an urban community of Oyo State, South west Nigeria: implication for policy action. African Health Sciences, 18(3), 776-785. https://doi.org/10.4314/ahs.v18i3.36

Idris, S. H., \& Sambo, M. N. (2009). Psycho-active substance use among in-school adolescents in Zaria, north western Nigeria: what are the triggers. Nigerian Journal of Medicine, 18 (3), 291-294. https://doi.org/10.4314/njm.v18i3.51191

Johnson, K., Courser, M., Holder, H., Miller, B., Ogilvie, K., Moore, R., ... \& Saylor, B. (2007). A community prevention intervention to reduce youth from inhaling and ingesting harmful legal products. Journal of drug education, 37(3), 227-247. https://doi.org/10.2190/DE.37.3.b

Lal, R., Deb, K. S., \& Kedia, S. (2015). Substance use in women: Current status and future directions. Indian J Psychiatry, 57(Suppl 2), S275-85. https://doi.org/10.4103/0019-5545.161491

Manyike, P. C., Chinawa, J. M., Chinawa, A. T., Obu, H. A., Nwokocha, A. R. C., \& Odetunde, O. I. (2016). Correlates for psycho-active substance use among boarding secondary school adolescents in Enugu, South East, Nigeria. BioMed Central Pediatrics, 16(78), 1-8. https://doi.org/10.1186/s12887-016-0615-9

Metha, C. R., \& Patel, N. R. (2009). Exact Tests (SPSS user guide), SPSS Inc., USA. (Downloaded: September 2009, http://support.spss.com.)

National Institute on Drug Abuse (NIDA). (2007). Understanding drug abuse and addiction: What science says.

Nwoga, C. N., Ndak, A. Z., Audu, M. D., Goar, S. G., Armiya'u, A. Y., Agbir, T. M. \& Dakwak, S. J. (2019). Pattern and Effect of Substance Use in Jos South, North Central, Nigeria. Journal of Research in Basic and 
Clinical Sciences, 1(2), 150-154.

Oetting, E. R., Plested, B., Edwards, R. W., Thurman, P. J., Kelly, K. J., Beauvais, F., \& Stanley, L. (2014). Community readiness for community change: Tri-Ethnic Center community readiness handbook. Edited by Stanley L, 2nd edn: Colorado State University.

Ostaszewski, K., \& Zimmerman, M. A. (2006). The effects of cumulative risks and promotive factors on urban adolescent alcohol and other drug use: A longitudinal study of resiliency. American journal of community psychology, 38(3-4), 251-262. https://doi.org/10.1007/s10464-006-9076-x

Rehm, J., \& Hingson, R. (2013). Measuring the burden - Alcohol's evolving impact on individuals, families, and society. Alcohol Research: Current Reviews, 35(2).

Sadock, B. J., \& Sadock, V. A. (2003). Kaplan and Sadock's comprehensive textbook of psychiatry (7 $7^{\text {th }}$ ed.). Lippincott, Williams and Wilkins: Philadelphia.

Radin, S. M., Kutz, S. H., La Marr, J., Vendiola, D., Vendiola, M., Wilbur, B., ... \& Donovan, D. M. (2015). Community perspectives on drug/alcohol use, concerns, needs, and resources in four Washington State tribal communities. Journal of ethnicity in substance abuse, 14(1), 29-58. https://doi.org/10.1080/15332640.2014.947459

Solis, J. M., Shadur, J. M., Burns, A. R., \& Hussong, A. M. (2012). Understanding the diverse needs of children whose parents abuse substances. Current drug abuse reviews, 5(2), 135-147. https://doi.org/10.2174/1874473711205020135

Substance Abuse and Mental Health Services Administration. (2019). A Guide to SAMHSA's Strategic Prevention Framework. Rockville, MD: Center for Substance Abuse Prevention. https://www.samhsa.gov/sites/default/files/20190620-samhsa-strategic-prevention-framework-guide.pdf

Substance Abuse and Mental Health Services Administration, Focus on Prevention. HHS Publication No. (SMA) 10-4120. Rockville, MD: Center for Substance Abuse Prevention, Substance Abuse and Mental Health Services Administration, Revised 2017.

Unaogu, N. N., Onu, J. U., Iteke, O., Tukur, K., \& Oka, I. Q. (2017). Pattern of substance at the drug de-addiction unit of a Nigerian psychiatric hospital. African Journal of Drug and alcohol Studies, 16(1).

United Nations Office on Drugs - UNODC (2004), Crime, and Global Youth Network. Schools: School-based Education for Drug Abuse Prevention. United Nations Publications.

United Nations Office on Drugs and Crime - UNODC (2018). Drug use in Nigeria. Retrieved from https://www.unodc.org/documents/data-and-analysis/statistics/Drugs/Drug_Use_Survey_Nigeria_2019_BO OK.pdf

Whiteford, H. A., Degenhardt, L., Rehm, J., Baxter, A. J., Ferrari, A. J., Erskine, H. E., ... \& Vos, T. (2013). Global burden of disease attributable to mental and substance use disorders: Findings from the Global Burden of Disease Study 2010. Lancet, 382, 1575-1586. https://doi.org/10.1016/S0140-6736(13)61611-6

World Health Organization. (2014). Global status report on alcohol and health. In: Global status report on alcohol, 1-392. Geneva, Switzerland: Author. http://www.who.int/substance_abuse/publications/global_alcohol_report/en/

World Health Organization. (2012). People with drug dependence need better access to health care. Geneva, Switzerland: The Author. https://www.who.int/mediacentre/news/notes/ 2012/drug_use_20120626/en/

\section{Copyrights}

Copyright for this article is retained by the author(s), with first publication rights granted to the journal.

This is an open-access article distributed under the terms and conditions of the Creative Commons Attribution license (http://creativecommons.org/licenses/by/4.0/). 